\title{
Highly complex respiratory changes in calf
}

\section{Alterações respiratórias de alta complexidade em bezerro}

\author{
Rodrigo Malzoni de SOUZA ${ }^{1}$; Camila Freitas BATISTA ${ }^{1}$; Kamila Reis SANTOS ${ }^{1}$; Renata Caminha GOMES ${ }^{1}$; \\ Heloisa Godoi BERTAGNON²; Alice Maria Melville Paiva DELLA LIBERA ${ }^{1}$ \\ ${ }^{1}$ Universidade de São Paulo, Faculdade de Medicina Veterinária e Zootecnia, São Paulo - SP, Brazil \\ ${ }^{2}$ Universidade Estadual do Centro-Oeste, Guarapuava, Paraná - PR, Brazil
}

\begin{abstract}
The bronchopneumonia of calves represents a risk to national supply chain because it is an ecopathy and weakens the more intensive production systems. It is characterized by inflammatory changes in the bronchi, bronchioles, lung parenchyma, and pleura. It is a disease of multifactorial traits called Bovine Respiratory Disease (BRD). The association of infectious agents with host defense and management to which the animal is subjected leads to the emergence of major clinical manifestations of the disease. The clinical evolution of BRD can also have serious secondary changes such as pulmonary edema, sepsis, and pulmonary hypertension, or even be consequent to the involvement of other structures, such as in cases of myocarditis leading to congestive heart failure. Although this report refers to a nonexperimental framework, the circumstances that caused the calf to be subjected to a protocol-specific respiratory assessment involving non-routine reviews have made it possible to associate circulatory and respiratory conditions, rarely considered in ruminant clinics. The focus of this report was pulmonary edema. Modern clinical vision requires work with cost-benefit relation by the veterinarian, and the more accurate and the earlier the clinical diagnosis the less expensive the treatment.
\end{abstract}

Keywords: Bronchopneumonia. Pulmonary edema. Sepsis. Myocarditis. Cattle. Prognosis. Treatment.

\section{Resumo}

A broncopneumonia dos bezerros representa um risco à cadeia produtiva nacional por ser uma ecopatia e por fragilizar os sistemas de produção mais intensivos. É caracterizada por alterações inflamatórias de brônquios, bronquíolos, parênquima pulmonar e pleura. Por ser uma doença de características multifatoriais, é denominada Complexo Doença Respiratória de Bovinos (CDRB). A interação dos agentes infecciosos, a defesa do hospedeiro e o manejo ao qual o animal é submetido determinam as principais manifestações clínicas da doença. A evolução clínica do CDRB também pode apresentar alterações secundárias graves como o edema pulmonar, a septicemia e a hipertensão pulmonar, ou mesmo ser consequente ao comprometimento de outras estruturas, como nos casos de miocardite que levam à insuficiência cardíaca congestiva. Apesar de este relato referir-se a um quadro não experimental, as circunstâncias de submissão a um protocolo de avaliação respiratória específico, envolvendo avaliações não rotineiras, permitiram associar as interações circulatórias e o quadro respiratório, algo pouco considerado em clínicas de ruminantes. O foco deste relato foi o edema pulmonar. A visão clínica moderna obriga o médico veterinário a trabalhar a relação custobenefício, e quanto mais acurado e precoce é o diagnóstico clínico, menos dispendioso é o tratamento.

Palavras-chave: Broncopneumonia. Edema pulmonar. Septicemia. Miocardite. Bovinos. Prognóstico. Tratamento.

\section{Correspondence to:}

Rodrigo Malzoni de Souza

Universidade de São Paulo, Faculdade de Medicina Veterinária

e Zootecnia

Av. Orlando Marques de Paiva, 87

CEP 05508-270, São Paulo, SP, Brazil

e-mail: rodrigomalzoni@usp.br

Received: 26/09/2016

Approved: 07/11/2017

In Brazil as in other countries where cattle farming is significant higher calf mortality rates are recorded during the first month of life (BENESI, 1993), and bronchopneumonia is considered a very important problem, reaching $12.7 \%$ of calves raised in extensive system and constituting between $13 \%$ and $23.9 \%$ of the diseases that affect calves under one year of age (RABELO et al., 1996). Despite being a common disease, there is a different prognosis and the establishment of this is crucial for the design of the damage caused by this important nosological complex. The main research on the subject describes economic losses arising from the impairment of development (BLUM et al., 1996), mortality, infectious aspects, and risk factors (COUTINHO, 2004). 
However, the clinical course of Bovine Respiratory Disease (BRD), especially bronchopneumonic, may present serious secondary changes such as pulmonary edema (MORLÁN, 2003), sepsis, and pulmonary hypertension, or even be consequence of the involvement of other structures, such as in cases of myocarditis (MCGAVIN; ZACHARY, 2009), which requires formation of the clinic and allows different expectations.

In this paper, the interactions that can compromise the patient's prognosis will be discussed and presented in the form of highly complex respiratory changes.

This report refers to a bovine male Holstein, three months old, with historic of prostration, lack of appetite, dyspnea, and fever for about two hours. It was an animal subjected to adequate colostration, confirmed by determining total serum protein proven by refractometry. The same had been followed clinically by daily general physical examination. No changes had been found so far to justify such manifestations.

Upon physical examination the animal was lethargic in sternal recumbency, presented tachycardia $(\mathrm{HR}=128 \mathrm{bpm})$, tachypnea $(\mathrm{RR}=80 \mathrm{mpm})$, fever $\left(\mathrm{T}^{\circ} \mathrm{C}=40,8^{\circ} \mathrm{C}\right)$, and palpebral conjunctiva were flushed. In the specific examination of the respiratory system, on palpation the cough reflex was negative, and dullness to percussion and auscultation to rattle wet were identified. Endoscopic examination of the airways was performed because the episode had occurred after feeding and there was suspicion of obstruction. This fact was not confirmed, as evidenced pulmonary edema by the amount of foamy translucent content in the trachea and main bronchi, as well as respiratory acidosis, which was confirmed by blood gas analysis (Table 1).

Table 1 - Results of laboratory test (hemogasometry) made on the first day of service of a calf with respiratory changes - São Paulo, 2013

\begin{tabular}{lcc}
\hline & Day 01 & Reference value* \\
\hline pH & 7,28 & $7,31-7,53$ \\
pO2 (mmHg) & 21,8 & $>85$ \\
pCO2 (mmHg) & 67,7 & $35-44$ \\
HCO3- (mEq/L) & 31,7 & $17-29$ \\
Osmolality (mOsm/kg) & 253,5 & $270-300$ \\
Anion gap (mmol/L) & 12,6 & $14-20$ \\
\hline
\end{tabular}

* Smith (2006)

In the case of an acute and emergency framework, the protocol was instituted furosemide $(2.0 \mathrm{mg} / \mathrm{kg})$, dexamethasone (single dose of $0.3 \mathrm{mg} / \mathrm{kg}$ ), dipyrone
(25 mg/kg), and enrofloxacin (5.0 mg/kg). The animal was also submitted to oxygen therapy for two hours with a PO2 arterial of $59 \mathrm{mmHg}$.

The result was immediate, heart and respiratory rate normalized, as well as the temperature of $40,8^{\circ} \mathrm{C}$ regressed to $39,4^{\circ} \mathrm{C}$. Subsequent daily monitoring of the animal showed an improvement of clinical signs presented. Furosemide and dexamethasone were maintained for two days and seven days of enrofloxacin, with apparent remission.

After 25 days of the diagnosis of pulmonary edema, the animal expressed a critical episode similar to the above. Blood count, biochemistry, and blood gas analysis were requested. The same treatment was carried out but with the substitution of enrofloxacin for ceftiofur $(2.2 \mathrm{mg} / \mathrm{kg})$ and the addition of aminophylline $(6.0 \mathrm{mg} / \mathrm{kg})$.

Based on clinical symptoms, history, and physical and laboratory tests, there was suspicion of a disease in the circulatory system to justify the recurrent respiratory changes. Therefore, three tests were required: echocardiography, measurement of cardiac troponin I, and measurement of ECG by Holter. In the echocardiography a decrease in ventricular contractility the value of cardiac troponin I was observed, higher $(0.07 \mathrm{ng} / \mathrm{mL})$ when compared to a healthy calf; the ECG by Holter showed no changes.

The animal was not responsive to treatment in the second episode, coming to death seven days later. In the macroscopic findings of the autopsy, pulmonary congestion was observed, with the presence of plaques of fibrinous exudate, also present in the trachea, as well as a foamy content. In other organs there was no noticeable changes of note.

The first clinical evidence shows pulmonary edema. At the time, the picture presented sudden onset and was admitted to the animal actually being systematically subjected to physical examination, specific examination of the respiratory system, complete with blood tests and endoscopic airway for healthy animal image registration.

At diagnosis of edema, it also had increased temperature, as described in cases of acute pulmonary edema (WILSON; LOFSTEDT, 1990; GONÇALVES et al., 2001).

The consequences of an inflammatory process along the feverish process led to the animal prostration (LIVINGSTON, 2000; HAZEWINKEL et al., 2008).

The framework required emergency measures that have been adopted, and treatment was established 
according to many authors (HAWKINS, 1997; NELSON; COUTO, 2006). The principles of therapy include pulmonary edema reduction activity, the patency of the air passages, reduction in alveolar hypoxia, improved blood oxygenation and tissues, and the correction of acidbase imbalances.

Furosemide at dose of $2.0 \mathrm{mg} / \mathrm{kg}$ provided comfort to the animal every time it was administered. According to Nelson and Couto (2006), diuretics are quite effective in relieving pulmonary edema in the early stages, but this effect tends to decrease with the progression of the cause of the edema. Furosemide and its loop diuretic effect reduces afterload and improves left ventricular emptying, reducing pulmonary congestion and decreasing myocardial oxygen consumption.

The oxigenotherapy held in two stages improved the breathing capacity of the animal. Nelson and Couto (2006) state that it is suitable for all patients with signal of respiratory distress.

The dipyrone was administered at a dose of $25 \mathrm{mg} / \mathrm{kg}$ intravenously or intramuscularly every time the animal had fever - depending on how high the temperature and the clinical condition of the animal was. Within three to four hours the temperature decreased considerably. Kallmünzer et al. (2011) intervened in 331 cases of fever with the sequential administration of paracetamol and dipyrone, which resulted in a significant drop in body temperature of calves after 60 minutes.

There are no reports of corticosteroids indicated for the treatment of pulmonary edema. Nevertheless, knowing the action of corticosteroids and since the animal had already been diagnosed with bronchopneumonia, the drug was administered at the dose of $0.3 \mathrm{mg} / \mathrm{kg}$ in three different episodes. After intravenous administration, there was clear symptomatic improvement, primarily through appetite and attitude.

The radiographic examination was not performed due to remission of symptoms and also of a portable device at that time, since it would be impracticable to take the animal to the radiology block due to stress.

After 25 days the animal had a second episode of edema, demonstrating a greater lung commitment. Firstly, we carried out the exchange of the ceftiofur antibiotic for the dose of $2.2 \mathrm{mg} / \mathrm{kg}$ every 24 hours for six days, believing in the resistance of the bacterial agent to the previously administered antibiotic. The ceftiofur hydrochloride is an antibiotic from the class of third generation cephalosporins having a broad spectrum of action.
Aminophylline was added to the treatment at a dosage of $6.0 \mathrm{mg} / \mathrm{kg}$, which according to the authors Hawkins (1997) and Morlán (2003) is a bronchodilator - methylxanthine, which has positive inotropic, diuretic, and bronchodilatory properties, and increases diaphragmatic contraction.

Nonsteroidal anti-inflammatory (flunixin meglumine), bronchodilators (broxemina hydrochloride), and fluid, as well as lactated Ringer's saline were added to maintain the treatment of the animal (CARDOSO et al., 2002; COUTINHO, 2004), but it was not successful.

Echocardiography provides information about the anatomical variations, endocardial lesions, congenital anomalies, tumors, and pericardial disease. This is indicated for animals with genetic value, which show signs of heart disease for which one cannot reach a specific diagnosis (PEEK; MCGUIRK, 2008). In the animal in question a decrease in cardiac contractility and vitality of low strength ventricular contraction was observed, similar to what Mendes et al. (1994) described in frames of myocarditis. Nevertheless, expansion of the chambers, mitral and tricuspid insufficiency, pericardial effusion, and intracardiac thrombosis were not found.

Echocardiographic evaluations in ruminants are restricted and Michima (2007), which described the echocardiographic evaluation technique for calves and said characteristics of evaluations of cardiac calves cameras providing this information to clinical use. In 2010, Pogliani used this resource for cardiac evaluation in cloned calves derived from nuclear transfer from adult somatic cells, and this study relates to the respiratory condition in calf Holstein with three months of age. Following the evaluation criteria proposed by Michima (2007) and Pogliani (2010) no changes were identified.

O'Brien (2008) states that there are no specific biomarkers for the diagnosis of myocarditis in bovine medicine. Although creatine kinase, lactate dehydrogenase, and its isoenzymes in human and animals are used for the detection of myocardial damage, the effective use of these enzymes is limited due to the lack of tissue specificity and sensitivity.

Many authors (ALPERT et al., 2000; O’BRIEN, 2008) report that the best cardiac biomarker for myocardial damage is the determination of cardiac troponin concentration ( $\mathrm{cTnI}$ and $\mathrm{cTnT}$ ), because they have specificity almost completely by the myocardial tissue and greater sensitivity than other biomarkers. According to the American College of Cardiology and The European Society of Cardiology, troponin is regarded as a preferred 
biomarker for infarction (ALPERT et al., 2000) and has become the subject of research in veterinary medicine in recent years. Some assays have been developed in several animal species for determination of human troponin (OYAMA; SISSON, 2004; MICHIMA, 2007; LEONARDI et al., 2008), while bovine cardiac troponin can be used as a biomarker for heart disease in cattle (KARAPINAR et al., 2010).

This study was performed with cTnI measurement yielding a value of $0.07 \mathrm{ng} / \mathrm{ml}$. It was considered the high value when compared to the result of a healthy calf, which was $0.00 \mathrm{ng} / \mathrm{mL}$. Similar to this result, Varga et al. (2013) conducted research on cTnI cows with various diseases, including pneumonia observed that the median value for cTnI was $0.03 \mathrm{ng} / \mathrm{ml}$ and the maximum value of $0.05 \mathrm{ng} / \mathrm{ml}$, while in healthy animals this value did not exceed $0.02 \mathrm{ng} / \mathrm{ml}$.

Likewise, the increase in cTnI has been identified in people with heart diseases like sepsis (DE GENNARO et al., 2008; TSAI et al., 2008) and septic shock (DE GENNARO et al., 2008; LAZZERI et al., 2008), embolism (MARGATO et al., 2009), and chronic obstructive pulmonary disease (FRUCHTER; YIGLA, 2009). Similar findings have been reported in foals with septicemia (SLACK et al., 2005) and calves with experimentally induced endotoxemia (PEEK; MCGUIRK, 2008).

From the assessment of these works with the current one, it may be inferred that the dosage of $\mathrm{cTnI}$ is important not only to investigate the extent of primary cardiac lesions, but also as a useful tool in the search for the presence of secondary cardiac complications or vice versa.

As for the Holter method adopted for the evaluation, standardized criteria for dogs (MAZINI, 2011) was used, since there are no descriptions for ruminants, currently in the process of standardization.

From these tests it was possible to prove a myocardial dysfunction in the context, but it was not possible to say if it was primary or secondary. Since it may have caused pulmonary edema framework, which led to a weakness of this body causing pneumonia, and for being a shock organ led to sepsis, or pneumonia caused sepsis leading to a myocardium dysfunction.

GENOVEZ, M. E. Importância do diagnóstico diferencial em um surto de pneumonia enzoótica bovina. Arquivos do Instituto Biológico, v. 69, n. 3, p. 111-113, 2002.

COUTINHO, A. S. Mannheimiose pneumônica experimentalmente induzida em bezerros pela Mannheimia (Pasteurella) haemolytica A1 - cepa D153: achados do exame físico, hemograma e swabs nasal e nasofaringeano. 2004. 186 f. Tese (Doutorado em Medicina Veterinária) - Faculdade de Medicina Veterinária e Zootecnia, Universidade Estadual Paulista, Botucatu, 2004.

DE GENNARO, L.; BRUNETTI, N. D.; CUCUlO, A.; PELlEGRINO, P. L.; IZZO, P.; ROMA, F.; DI BIASE, M. Increased troponin levels in nonischemic cardiac conditions and noncardiac diseases. Journal of Interventional Cardiology, v. 21, n. 2, p. 129-39, 2008. doi: 10.1111/j.1540-8183.2007.00336.x.

FRUCHTER, O.; YIGLA, M. Cardiac troponin-I predicts long term mortality in chronic obstructive

TEIXEIRA, S. R.; MIYASHRO, A.; CAMPOS, F. R.; 
pulmonary disease. Journal of Chronic Obstructive Pulmonary Disease, v. 6, n. 3, p. 155-61, 2009. doi: 10.1080/15412550902902620.

GONÇALVES, R. C.; KUCHEMBUCK, M. R. G.; CURI, P. R.; CHIACCHIO, S. B.; ALMEIDA, C. T.; BORGES, A. S. Diferenciação clínica da broncopneumonia moderada e graveembezerros.Ciência Rural,v.31,n.2,p.263-269, 2001. doi: 10.1590/S0103-84782001000200012.

HAWKINS, E. C. Afecções do sistema respiratório inferior. In: ETTINGER, S. J.; FELDMAN, E. C. Tratado de medicina interna veterinária. 4. ed. São Paulo: Manole, 1997. p. 1080-1142. 1 v.

HAZEWINKEL, H. A.; VAN DEN BROM, W. E.; THEYSE, L. F.; POLLMEIER, M.; HANSON, P. D. Comparison of the effects of firocoxib, carprofen and vedaprofenin a sodium urate crystal induced synovitis model of arthritis in dogs. Research in Veterinary Science, v. 84, n. 1, p. 74-79, 2008. doi: 10.1016/j.rvsc.2007.02.005.

KALLMÜNZER, B.; KRAUSE, C.; PAULI, E.; BECK, A.; BREUER, L.; KÖHRMANN, M.; KOLLMAR, R. Standardized antipyretic treatment in stroke: a pilot study. Cerebrovascular Diseases, v. 31, n. 4, p. 382-389, 2011. doi: 10.1159/000321733.

KARAPINAR, T.; DABAK, D. O.; KULOGLU, T.; BULUT, $\mathrm{H}$. High cardiac troponin I plasma concentration in a calf with myocarditis. The Canadian Veterinary Journal, v. 51, n. 4, p. 397-399, 2010.

LAZZERI, C.; BONIZZOLI, M.; CIANCHI. G.; GENSINI, G. F.; PERIS, A. Troponin I in the intensive care unit setting: from the heart to the heart. Internal and Emergency Medicine, v. 3, n. 1, p. 9-16, 2008. doi: 10.1007/s11739-008-0089-3.

LEONARDI, F.; PASSERI, B.; FUSARI, A.; DE RAZZA, P.; BEGHI, C.; LORUSSO, R.; CORRADI, A.; BOTTI, P. Cardiac troponin I (cTnI) concentration in an ovine model of myocardial ischemia. Research in Veterinary Science, v. 85, n. 1, p. 141-144, 2008. doi: 10.1016/j.RVSC.2007.09.010.

LIVINGSTON, A. Mechanism of nonsteroidal antiinflammatory drugs. Veterinary Clinics of North
America:SmallAnimal Practice,v.30,n.4,p.773-781, 2000. doi: 10.1016/S0195-5616(08)70006-8.

MARGATO, R.; CARVALHO, S.; RIBEIRO, H.; MATEUS, P.; FONTES, P.; MOREIRA, J. I. Cardiac troponin I levels in acute pulmonary embolism. Revista Portuguesa de Cardiologia, v. 28, n. 11, p. 1213-1222, 2009.

MAZINI, A. M. Avaliação da ocorrência de arritmias e da variabilidade da frequência cardíaca em cães obesos pelo método Holter. 2011. 144 f. Dissertação (Mestrado em Ciências) - Faculdade de Medicina Veterinária e Zootecnia, Universidade de São Paulo, São Paulo, 2011. doi: 10.11606/D.10.2011.tde-25092012-112844.

MCGAVIN, D. M.; ZACHARY, J. F. Bases da patologia em veterinária. 4. ed. Rio de Janeiro: Mosby Elsevier, 2009.

MENDES, L. A.; DEC, G. W.; PICARD, M. H.; PALACIOS, I. F.; NEWELL, J.; DAVIDOFF, R. Right ventricular dysfunction: an independent predictor of adverse outcome in patients with myocarditis. American Heart Journal, v. 128, n. 2, p. 301-307, 1994. doi: 10.1016/00028703(94)90483-9.

MICHIMA, L. E. S. Influência do exercício físico prolongado sobre a concentração sérica de troponina I cardíaca e sobre a função cardíaca em cavalos de enduro. 2007. 94 f. Tese (Doutorado em Medicina Veterinária) - Faculdade de Medicina Veterinária e Zootecnia, Universidade de São Paulo, São Paulo, 2007.

MORLÁN, J. L. R. Edema pulmonar. In: BELERENEAN, G. C.; MUCHA, C. J.; CAMACHO, A. A. Afecções cardiovasculares em pequenos animais. São Paulo: Interbook, 2003. p. 204-211.

NELSON, R. W.; COUTO, C. G. Medicina interna de pequenos animais. 3. ed. Rio de Janeiro: Elsevier, 2006.

O'BRIEN, P. J. Cardiac troponin is the most effective translational safety biomarker for myocardial injury in cardiotoxicity. Toxicology, v. 245, n. 3 p. 206-218, 2008. doi: 10.1016/j.tox.2007.12.006.

OYAMA, M. A.; SISSON, D. D. Cardiac troponin-I concentration in dogs with cardiac disease. Journal of 
Veterinary Internal Medicine, v. 18, n. 6, p. 831-839, 2004. doi: 10.1111/j.1939-1676.2004.tb02629.x.

PEEK, S. F.; MCGUIRK, S. M. Cardiovascular diseases. In: DIVERS, T. J.; PEEKS, S. F. (Eds.). Rebhun's diseases of dairy cattle. 2. ed. Saint Louis: Saunders, 2008. p. 43-78.

POGLIANI, F. C. Parâmetros ecodopplercardiográficos de bezerros da raça Nelore originados através de transferência nuclear de células somáticas adultas: clonagem. 2010. 107 f. Tese (Doutorado em Medicina Veterinária) - Faculdade de Medicina Veterinária e Zootecnia, Universidade de São Paulo, São Paulo, 2010.

RABELO, S. S. A.; LIMA JUNIOR, A. D.; CASTRO, R. S.; TABOSA, J. H. C. Sazonalidade da broncopneumonia em bezerros da microrregião de Garanhuns, Pernambuco (1983-1991). Arquivos Brasileiros de Medicina Veterinária e Zootecnia, v. 48, n. 1, p. 19-26, 1996.

SLACK, J. A.; MCGUIRK, S. M.; ERB, H. N.; LIEN, L.; COOMBS, D.; SEMRAD, S. D.; RISEBERG, A.; MARQUES, F.; DARIEN, B.; FALLON, L.; BURNS, P.; MURAKAMI, M. A.; APPLE, F. S.; PEEK, S.F. Biochemical markers of cardiac injury in normal, surviving septic, or non- surviving septic neonatal foals. Journal of Veterinary Internal Medicine, v. 19, n. 4, p. 577-580, 2005. doi: 10.1111/j.1939-1676.2005.tb02730.x.

SMITH, B. P. Medicina interna de grandes animais. 3. ed. São Paulo: Manole, 2006. 1784 p.

TSAI, S. H.; CHU, S. J.; HSU, C. W.; CHENG, S. M.; YANG, S. P. Use and interpretation of cardiac troponins in the ED. The American Journal of Emergency Medicine, v. 26, n. 3, p. 331-341, 2008. doi: 10.1016/j.ajem.2007.05.031.

VARGA, A.; ANGElOS, J. A.; GRAHAM, T. W.; CHIGERWE, M. Preliminary investigation of cardiac troponin I concentration in cows with common production diseases. Journal of Veterinary Internal Medicine, v. 27, n. 6, p. 1613-1621, 2013. doi: 10.1111/jvim.12213.

WILSON, J. H.; LOFSTEDT, J. Alterations in respiratory function. In: SMITH, B. (Ed.). Large animal internal medicine: diseases of horses, cattle, sheep and goats. St. Louis: C.V., 1990. p. 47-99. 